Original research article

\title{
Falcarindiol and dichloromethane fraction are bioactive components in Oplopanax elatus: Colorectal cancer chemoprevention via induction of apoptosis and G2/M cell cycle arrest mediated by cyclin A upregulation
}

\author{
Chong-Zhi Wang ${ }^{1,2 * \#, ~ Y u n ~ L u o ~}{ }^{1,2 \#}$, Wei-Hua Huang ${ }^{2}$, Jinxiang Zeng ${ }^{2}$, Chun-Feng Zhang ${ }^{2}$, \\ Mallory Lager ${ }^{2}$, Wei Du ${ }^{3}$, Ming Xu ${ }^{4}$, Chun-Su Yuan ${ }^{2,4}$ * \\ ${ }^{1}$ Ministry of Education, Jiangxi University of Traditional Chinese Medicine, Key Laboratory of Modern Preparation of Traditional Chinese Medicine, \\ Nanchang, P.R. China \\ ${ }^{2}$ University of Chicago, Tang Center for Herbal Medicine Research, and Department of Anesthesia and Critical Care, Chicago, Illinois, USA \\ ${ }^{3}$ University of Chicago, Ben May Department for Cancer Research, Chicago, Illinois, USA \\ ${ }^{4}$ University of Chicago, Committee on Clinical Pharmacology and Pharmacogenomics, Chicago, Illinois, USA
}

\section{Abstract}

Oplopanax elatus (Nakai) Nakai has a long history of use as an ethnomedicine by the people living in eastern Asia. However, its bioactive constituents and cancer chemopreventive mechanisms are largely unknown. The aim of this study was to prepare O. elatus extracts, fractions, and single compounds and to investigate the herb's antiproliferative effects on colon cancer cells and the involved mechanisms of action. Two polyyne compounds were isolated from O. elatus, falcarindiol and oplopandiol. Based on our HPLC analysis, falcarindiol and oplopandiol are major constituents in the dichloromethane $\left(\mathrm{CH}_{2} \mathrm{Cl}_{2}\right)$ fraction. For the HCT-116 cell line, the dichloromethane fraction showed significant effects. Furthermore, the IC50 for falcarindiol and oplopandiol was $1.7 \mu \mathrm{M}$ and $15.5 \mu \mathrm{M}$, respectively. In the mechanistic study, after treatment with $5 \mu \mathrm{g} / \mathrm{ml}$ for $48 \mathrm{~h}$, dichloromethane fraction induced cancer cell apoptosis by $36.5 \%(p<0.01 \%$ vs. control of 3.9\%). Under the same treatment condition, dichloromethane fraction caused cell cycle arrest at the G2/M phase by $32.6 \%$ ( $p<0.01 \%$ vs. control of $23.4 \%$ ), supported by upregulation of key cell cycle regulator cyclin A to $21.6 \%$ ( $p<0.01 \%$ vs. control of $8.6 \%$ ). Similar trends were observed by using cell line HT-29. Data from this study filled the gap between phytochemical components and the cancer chemoprevention of $O$. elatus. The dichloromethane fraction is a bioactive fraction, and falcarindiol is identified as an active constituent. The mechanisms involved in cancer chemoprevention by O. elatus were apoptosis induction and G2/M cell cycle arrest mediated by a key cell cycle regulator cyclin A.
\end{abstract}

Keywords: Apoptosis; Cell cycle; Colorectal cancer; Cyclin A; Dichloromethane fraction; Falcarindiol; Oplopanax elatus

Highlights:

- Falcarindiol and oplopandiol are isolated from Oplopanax elatus $\mathrm{CH}_{2} \mathrm{Cl}_{2}$ fraction.

- O. elatus $\mathrm{CH}_{2} \mathrm{Cl}_{2}$ fraction is an active fraction on colon cancer cells.

- O. elatus $\mathrm{CH}_{2} \mathrm{Cl}_{2}$ fraction induces colon cancer cell apoptosis.

- O. elatus $\mathrm{CH}_{2} \mathrm{Cl}_{2}$ fraction induces $\mathrm{G} 2 / \mathrm{M}$ cell cycle arrest via cyclin A upregulation.

- Falcarindiol is an active constituent and significantly inhibits cancer cell growth.

\begin{abstract}
Abbreviations:
O. - Oplopanax; $\mathrm{CRC}$ - colorectal cancer; FITC - fluorescein isothiocyanate; $\mathrm{CH}_{2} \mathrm{Cl}_{2}$ - dichloromethane; $\mathrm{BuOH}$ - n-butanol; $\mathrm{H}_{2} \mathrm{O}$ - water; DMSO - dimethylsulfoxide; PI - propidium iodide; NMR - nuclear magnetic resonance; HPLC - high performance liquid chromatography; FBS - fetal bovine serum; MTS - 3-(4,5-dimethylthiazol-2-yl)-5-(3-carboxymethoxyphenyl)-2-(4-sulfophenyl)2H-tetrazolium, inner salt; ANOVA - analysis of variance; NIH/NCCAM - National Institutes of Health/National Center for Complementary and Alternative Medicine.
\end{abstract}

\footnotetext{
* Corresponding authors: Chong-Zhi Wang and Chun-Su Yuan, University of Chicago, Tang Center for Herbal Medicine Research, and Department of Anesthesia and Critical Care, 5841 South Maryland Avenue, MC4028, Chicago, IL 60637, USA;

e-mail: czwang@uchicago.edu; CYuan@dacc.uchicago.edu; http://doi.org/10.32725/jab.2021.013

\# C.-Z. Wang and Y. Luo are co-first authors and contributed equally to this study.

Submitted: 2020-10-15 • Accepted: 2021-05-03 • Prepublished online: 2021-05-05

J Appl Biomed 19/2: 113-124•EISSN 1214-0287 • ISSN 1214-021X

(C) 2021 The Authors. Published by University of South Bohemia in České Budějovice, Faculty of Health and Social Sciences.

This is an open access article under the CC BY-NC-ND license.
} 


\section{Introduction}

Oplopanax is a small genus, which includes three species: O. elatus, O. horridus, and O. japonicus. O. horridus and O. japonicus are distributed throughout the Pacific Northwest of North America and Japan, respectively (Huang et al., 2014). O. elatus is distributed in eastern Asia, including northeastern China, Fareast Russia, and Korea (Huang et al., 2010). Although these three species are very close in taxonomy, the chemical composition and pharmacological activities are different (Calway et al., 2012; Huang et al., 2014). The main bioactive components from the root of $O$. elatus were polyynes, lignans, and phenylpropanoids (Huang et al., 2014). Phytochemical and pharmacological studies on another species in this genus, i.e., $O$. horridus, are more frequently reported than those of $O$. elatus (Calway et al., 2012; Jang et al., 2017; Wang et al., 2013). Thus, systematic bioactivity and the corresponding bioactive component characterization are critically needed for the effective use of $O$. elatus.

Oplopanax elatus (Nakai) Nakai has a long history of use as an ethnomedicine by the people living in eastern Asia, which was introduced in the Jilin Chinese Herbal Medicine (Changchun College of Traditional Chinese Medicine, 1970), and the claimed indication for O. elatus includes neurasthenia, schizophrenia, rheumatism, and cardiovascular diseases (Shikov et al., 2014). Data from human subjects suggest that O. elatus showed positive effects for the management of diabetes (Klimakova and Kazman, 1962), depression (Turova, 1974), rheumatic arthritis (Tian et al., 1985), and bacterial and fungal infections (Fu et al., 1997; Vereshchagin et al., 1982), with antioxidant and anti-inflammatory potentials (Kwon et al., 2020; Tian et al., 2019).

According to the book Chinese Materia Medica, O. elatus has characters of supplement qi, reinforces yang, frees network vessels and gets through impediments (Editorial Committee for Chinese Materia Medica 1999). Based on traditional Chinese medicine theory, cancer is caused by the obstruction of channels and network vessels. Due to O. elatus having the ability to free and break through the channels and network vessels, this herb may have the potential to prevent and/or treat cancer. Therefore, in recent years, O. elatus has been elected to investigate its cancer chemopreventive effects (Huang et al., 2014; Qiao et al., 2017; Wang et al., 2019a).

Colorectal cancer $(\mathrm{CRC})$ is one of the most common cancers in the Western world. In the United States, it is estimated that there will be 104,270 newly diagnosed CRC cases and 52,980 CRC-related deaths in 2021, indicating the inadequacy of the currently available therapeutic approaches (Siegel et al., 2021). Botanicals are an attractive source of new therapeutic candidate compounds, as a tremendous chemical diversity is found in millions of species of plants (Lee et al., 2019; Liu et al., 2019). The treatment of human cancer owes much to the important drugs that have been derived from plants (Cragg et al., 2009). With the advent of phytochemical and pharmacological technologies, medicinal plants are likely to provide many of the lead structures for the construction of novel compounds with enhanced anticancer properties (Huang et al., 2019; Wu et al., 2020).

The genus Oplopanax is a member of the family Araliaceae, where a well-known plant ginseng (genus Panax) belongs. Over the past twenty years, over ten thousand research papers on ginseng have been published; however, for the genus Oplopanax, only less than one hundred studies have been published, and most of them were linked to O. horridus. An- ticancer pharmacological investigations on Oplopanax genus plants have been reported, and the related literature can be traced back to 2006 (Tai et al., 2006). Thus, anticancer studies on Oplopanax herbs, especially O. elatus, are rare, although $O$. elatus has a wide region of distribution and in large quantity. Although clinical studies of its use for cancer are lacking, recent pre-clinical investigations revealed that bioactive components from $O$. elatus showed anti-proliferative and chemopreventive activities on different cancer cell lines (Qiao et al., 2017; Wang et al., 2019a). We conducted pharmacodynamics studies on this herb and observed that O. elatus components can enhance a chemotherapeutic agent's anticancer potential (Wang et al., 2019a, b). Reported O. elatus studies only used its extract or one fraction; systematic screening for different fractions and active constituent identification have not been conducted. Thus, the bioactive fractions and constituents of O. elatus and their cancer chemopreventive mechanisms are largely unknown.

In this study, we first prepared O. elatus extract, and three fractions were obtained. Then, two major constituents were isolated and identified from one fraction. The contents of representative compounds in the extract and fractions were analyzed. Anticancer effects of $O$. elatus extract and fractions were carefully evaluated and systematically compared, and the active fraction and compound were identified. The cancer cell growth inhibition involved in apoptosis induction and cell cycle arrest, including the key cell cycle regulator, were determined.

\section{Materials and methods}

\section{Chemicals and reagents}

All solvents were of high-performance liquid chromatography grade. Cell culture plasticware was obtained from Falcon Labware (Franklin Lakes, NJ) and Techno Plastic Products (Trasadingen, Switzerland). Glutamine, insulin trypsin, McCoy's 5A medium, and phosphate buffered saline were obtained from Mediatech, Inc. (Herndon, VA, USA). Penicillin and streptomycin were obtained from Sigma-Aldrich (St. Louis, MO). The CellTiter 96 Aqueous Solution Cell Proliferation Assay, an MTS assay kit, was obtained from Promega (Madison, WI). PI/RNase staining buffer was obtained from BD Biosciences Pharmingen (San Diego, CA). Annexin V-FITC apoptosis detection kit and FITC-conjugated cyclin A were obtained from BD Biosciences (San Jose, CA).

\section{Plant materials}

The dried roots of Oplopanax elatus (Nakai) Nakai were collected from Benxi (Liaoning, China), in the northeastern area of China, and authenticated by Prof. De-Qiang Dou at Liaoning University of Traditional Chinese Medicine. A voucher specimen (number OES-20150820) is deposited in the Institute of Clinical Pharmacology, Central South University, Hunan Province, China.

Preparation of extract, fractions and single compounds Air-dried, powdered root bark of $O$. elatus was extracted with methanol. The extraction method was boiling under reflux. The filtrate was collected, and the extraction procedure was repeated one more time on the residue. The combined filtrate was condensed under vacuum and lyophilized to yield dried O. elatus extract. The extract was suspended in water, then extracted with dichloromethane and n-butanol successively to give dichloromethane fraction $\left(\mathrm{CH}_{2} \mathrm{Cl}_{2}\right)$ and n-butanol frac- 
tion $(\mathrm{BuOH})$. Water phase was condensed under vacuum to give water fraction $\left(\mathrm{H}_{2} \mathrm{O}\right)$. The $\mathrm{CH}_{2} \mathrm{Cl}_{2}$ fraction was separated by preparative HPLC to afford compounds 1 and 2. Structures of isolated compounds were determined by a combination of spectroscopic analyses, including $1 \mathrm{H}$ and $13 \mathrm{C}$ NMR and mass spectroscopic data. The compounds are identified as (1) falcarindiol and (2) oplopandiol (Fig. 1).
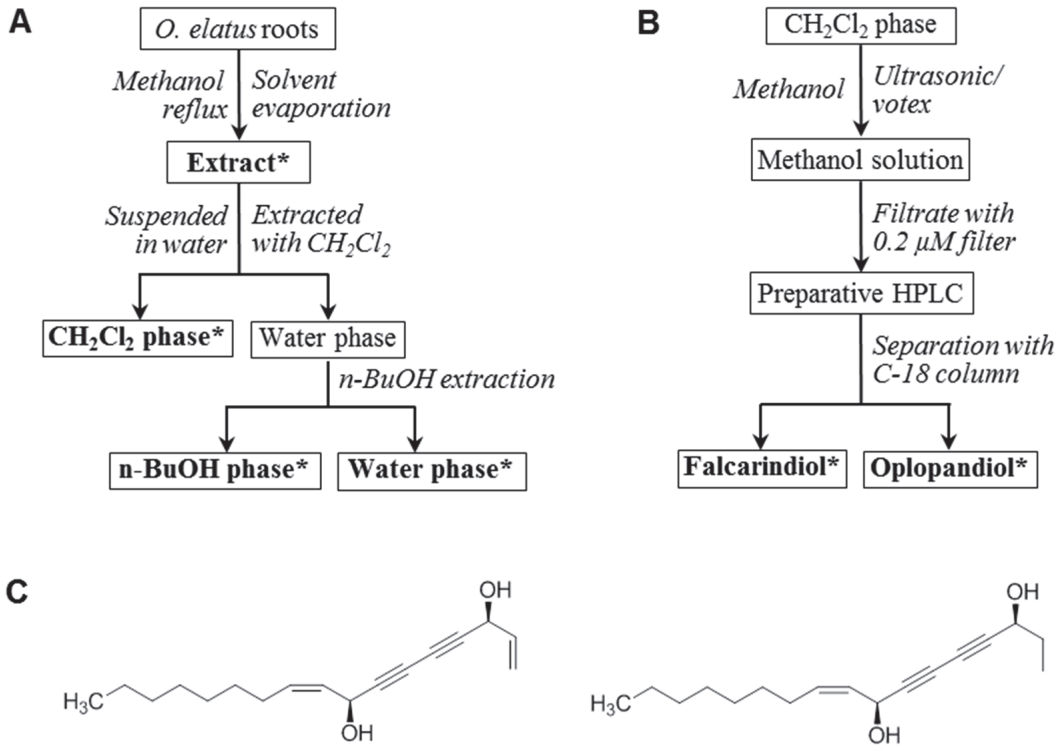

Falcarindiol

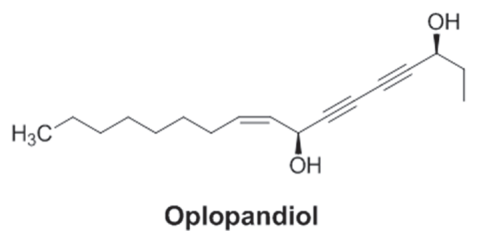

Fig. 1. Preparation of O. elatus fractions and single compounds. (A) Preparation flow chart for O. elatus extract and three fractions. (B) Isolation of representative single compounds from $\mathrm{CH}_{2} \mathrm{Cl}_{2}$ fraction. (C) Chemical structures of falcarindiol and oplopandiol;

* those extract/fractions/compounds were used for biological evaluations.

\section{HPLC analysis}

Chromatographic analysis was performed on a Waters 2960 HPLC system (Milford, MA, USA) with a quaternary pump, an automatic injector, a 996 photodiode array detector, and a Waters Empower software for peak identification. A gradient mobile phase system of acetonitriol (eluent A) and water (eluent B) was applied as follows: $36 \% \mathrm{~A}$ and $64 \% \mathrm{~B}(0 \mathrm{~min})$, $36 \% \mathrm{~A}$ and $64 \% \mathrm{~B}(10 \mathrm{~min}), 50 \% \mathrm{~A}$ and $50 \% \mathrm{~B}$ (20 min), $65 \% \mathrm{~A}$ and $35 \% \mathrm{~B}$ (35 min), $75 \% \mathrm{~A}$ and $25 \% \mathrm{~B}$ (40 min), 100\% $\mathrm{A}$ (45 min), 100\% A (50 min), 36\% A and 64\% B (53 min), and $36 \% \mathrm{~A}$ and $64 \% \mathrm{~B}$ (60 min). The flow rate was set at $1 \mathrm{ml} / \mathrm{min}$. The sample volume injected was set at $10 \mu \mathrm{l}$, and the detection wavelength was set at $202 \mathrm{~nm}$.

\section{Cell culture}

The research protocol was approved by the University of Chicago IACUC committee. The human colorectal cancer cell lines HCT-116 and HT-29 were purchased from the American Type Culture Collection (Manassas, VA, USA) and grown in McCoy's $5 \mathrm{~A}$ medium supplemented with $10 \% \mathrm{FBS}$ and $50 \mathrm{IU}$ penicillin/ streptomycin in a humidified atmosphere of $5 \% \mathrm{CO}_{2}$ at $37^{\circ} \mathrm{C}$.

\section{MTS assay}

O. elatus water fraction was dissolved in water. The extract, other fractions, and single compounds were dissolved in DMSO. HCT-116 and HT-29 cells were seeded in 96-well plates. After 1 day, various concentrations of extract/fractions/compounds were added to the wells. The final concentration of DMSO was $0.5 \%$. Controls were exposed to a culture medium containing $0.5 \%$ DMSO without drugs. Cell proliferation was evaluated using an MTS assay according to the manufacturer's instructions. Briefly, after 24-72 h treatment, the medium was re- placed with $100 \mu \mathrm{l}$ of fresh medium and $20 \mu \mathrm{l}$ of MTS reagent (CellTiter 96 Aqueous Solution) in each well, after which the plate was returned to the incubator for 1-4 h. A 60- $\mu$ l aliquot of medium from each well was transferred to an ELISA 96-well plate, and its absorbance at $490 \mathrm{~nm}$ was recorded. Results are expressed as percent of control (0.5\% DMSO control was set at $100 \%)$.

\section{Apoptotic assay}

Cancer cells were seeded in 24-well tissue culture plates. On the second day, the medium was changed, and tested botanical components were added. After treatment for $48 \mathrm{~h}$, the cells floating in the medium were collected. The adherent cells were detached with $0.05 \%$ trypsin. Then, the culture medium containing FBS (and floating cells) was added to inactivate the trypsin. After being pipetted gently, the cells were centrifuged for $5 \mathrm{~min}$ at $1500 \mathrm{~g}$. The supernatant was removed, and the cells were stained with annexin V-FITC and PI according to the manufacturer's instructions. Cells were analyzed immediately after staining using a FACScan flow cytometer (Becton Dickinson, Mountain View, CA) and FlowJo 10.6.1 software (Tree Star, Ashland, OR). For each measurement, at least 20,000 cells were counted.

\section{Cell cycle assay}

Cancer cells were seeded in 24-well tissue culture plates. On the second day, the medium was changed, and the cells were treated with different concentrations of tested samples. The cells were incubated for $48 \mathrm{~h}$ before harvesting. Next, the cells were gently fixed with $80 \%$ ethanol in a freezer for $2 \mathrm{~h}$ and then treated with $0.25 \%$ Triton X-100 for 5 min in an ice bath. The cells were resuspended in $300 \mu \mathrm{l}$ of PBS containing 
$40 \mu \mathrm{g} / \mathrm{ml} \mathrm{PI}$ and $0.1 \mathrm{mg} / \mathrm{ml}$ RNase, incubated in a dark room for $20 \mathrm{~min}$ at room temperature, and analyzed using a FACScan flow cytometer. For each measurement, at least 10,000 cells were counted.

\section{Cyclin A assay}

After $48 \mathrm{~h}$ treatment with the tested botanical components, cancer cells were harvested in a similar manner to that used in the cell cycle assay. The cells were stained with $300 \mu \mathrm{l}$ of PBS containing $40 \mu \mathrm{g} / \mathrm{ml} \mathrm{PI} \mathrm{and} 0.1 \mathrm{mg} / \mathrm{ml}$ RNase, and $20 \mu \mathrm{l}$ of cyclin A-FITC. Then, the cells were analyzed with a FACScan flow cytometer. For each measurement, at least 10,000 cells were counted.

\section{Statistical analysis}

Data are presented as mean \pm standard error (SE). A one-way ANOVA was employed to determine statistical significance of the results. In some cases, Student's $t$-test was used for comparing two groups. The level of statistical significance was set at $p<0.05$.

\section{Results}

HPLC analysis of O. elatus extract and three fractions

Based on our pilot study, we observed two major constituents in $\mathrm{CH}_{2} \mathrm{Cl}_{2}$ fraction. Using preparative HPLC, we prepared these two compounds from $\mathrm{CH}_{2} \mathrm{Cl}_{2}$ fraction, and they were identified as falcarindiol and oplopandiol, both belonging to polyynes. These two compounds were employed as standards for further HPLC analysis. The HPLC chromatograms of O. elatus extract and three fractions are shown in Fig. 2A. It indicates that the main constituents in extract were falcarindiol and oplopandiol. In dichloromethane fraction $\left(\mathrm{CH}_{2} \mathrm{Cl}_{2}\right)$, falcarindiol and oplopandiol were the major constituents, and peak areas of the two compounds are larger than that in the extract. On the other hand, the main constituents in n-butanol fraction $(\mathrm{BuOH})$ were still falcarindiol and oplopandiol; however, peak areas for the two compounds are much smaller than that in the extract and $\mathrm{CH}_{2} \mathrm{Cl}_{2}$ fraction. While in water fraction $\left(\mathrm{H}_{2} \mathrm{O}\right)$, only trace peaks were detected (Fig. 2A). As shown in
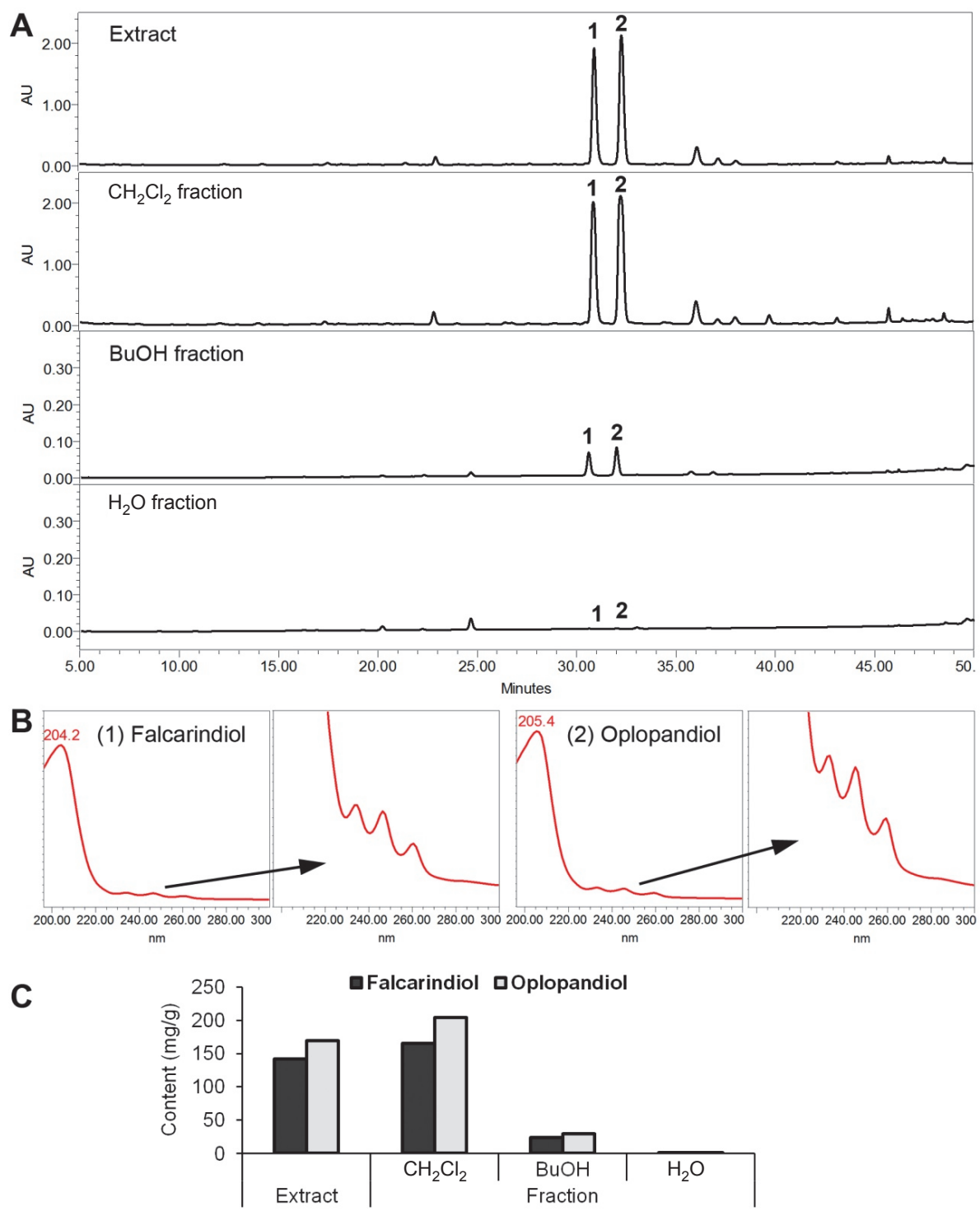

Fig. 2. HPLC analysis of O. elatus extract and fractions. (A) HPLC chromatograms recorded at $202 \mathrm{~nm}$. (B) UV spectra of falcarindiol and oplopandiol. Polyyne specific fingerprint between $220 \mathrm{~nm}$ and $270 \mathrm{~nm}$ has been shown. (C) Contents of falcarindiol and oplopandiol in extract and different fractions. $\mathrm{CH}_{2} \mathrm{Cl}_{2}$, dichloromethane fraction; $\mathrm{BuOH}$, n-butanol fraction; $\mathrm{H}_{2} \mathrm{O}$, water fraction. 
Fig. 2B, the UV spectra of the two compounds displayed the typical fingerprint of polyyne structure, and three peaks were observed between $220 \mathrm{~nm}$ and $270 \mathrm{~nm}$. The contents of the two determined polyynes in the extract and its three fractions are shown in Fig. 2C. In the extract, the content of falcarindiol and oplopandiol were 141.6 and $169.7 \mathrm{mg} / \mathrm{g}$, respectively. The content of falcarindiol and oplopandiol in $\mathrm{CH}_{2} \mathrm{Cl}_{2}$ fraction were 165.7 and $204.4 \mathrm{mg} / \mathrm{g}, 23.3$ and $29.0 \mathrm{mg} / \mathrm{g}$ in BuOH fraction, and 0.37 and $0.41 \mathrm{mg} / \mathrm{g}$ in $\mathrm{H}_{2} \mathrm{O}$ fraction, respectively (Fig. 2C). Falcarindiol and oplopandiol have the highest contents in $\mathrm{CH}_{2} \mathrm{Cl}_{2}$ fraction.

\section{Antiproliferative effects of 0 . elatus extract and fractions}

Two steps were applied to evaluate antiproliferative effects. In the first step, we investigated antiproliferative effects at one time point with relatively large intervals of concentrations for extract and all three fractions. As shown in Fig. 3A, for the cell line HCT-116, cell growth was absolutely inhibited by the treatment of extract and $\mathrm{CH}_{2} \mathrm{Cl}_{2}$ with a concentration of $25 \mu \mathrm{g} / \mathrm{ml} . \mathrm{H}_{2} \mathrm{O}$ fraction did not show any antiproliferative effects in the treatment concentration range. $\mathrm{BuOH}$ showed some cell growth inhibitory effects at $50 \mu \mathrm{g} / \mathrm{ml}$. Extract and $\mathrm{CH}_{2} \mathrm{Cl}_{2}$ showed potent effects. At 5 and $12.5 \mu \mathrm{g} / \mathrm{ml}$, the extract inhibited cell proliferation by $29.6 \%$ and $64.1 \%$, respectively, while at the same concentrations, $\mathrm{CH}_{2} \mathrm{Cl}_{2}$ fraction inhibited cell growth by $52.5 \%$ and $93.1 \%$, respectively. A similar trend was observed in HT-29 cells (Fig. 3A). Among the extract and three fractions, $\mathrm{CH}_{2} \mathrm{Cl}_{2}$ showed the strongest antiproliferative effects.

To further investigate antiproliferative potential, in the second step, time-, and dose-dependent effects were obtained. Cell proliferation was observed at 24,48 , and $72 \mathrm{~h}$. More precise concentration ranges were employed. For the HCT-116 cell group, treatment concentrations for extract and $\mathrm{CH}_{2} \mathrm{Cl}_{2}$ fraction were $1-20 \mu \mathrm{g} / \mathrm{ml}$ for $\mathrm{BuOH}$ fraction at $5-75 \mu \mathrm{g} / \mathrm{ml}$. For the HT-29 cell group, treatment concentrations for extract and $\mathrm{CH}_{2} \mathrm{Cl}_{2}$ fraction were $10-100 \mu \mathrm{g} / \mathrm{ml}$ for $\mathrm{BuOH}$ fraction at $50-400 \mu \mathrm{g} / \mathrm{ml}$. As shown in Fig. 3B, for the cell line HCT-116, after treatment with $\mathrm{CH}_{2} \mathrm{Cl}_{2}$ fraction, the cell proliferation decreased in a dose- and time-dependent manner by doses greater than $2.5 \mu \mathrm{g} / \mathrm{ml}$ ( $p<0.01$ vs. control). The extract also
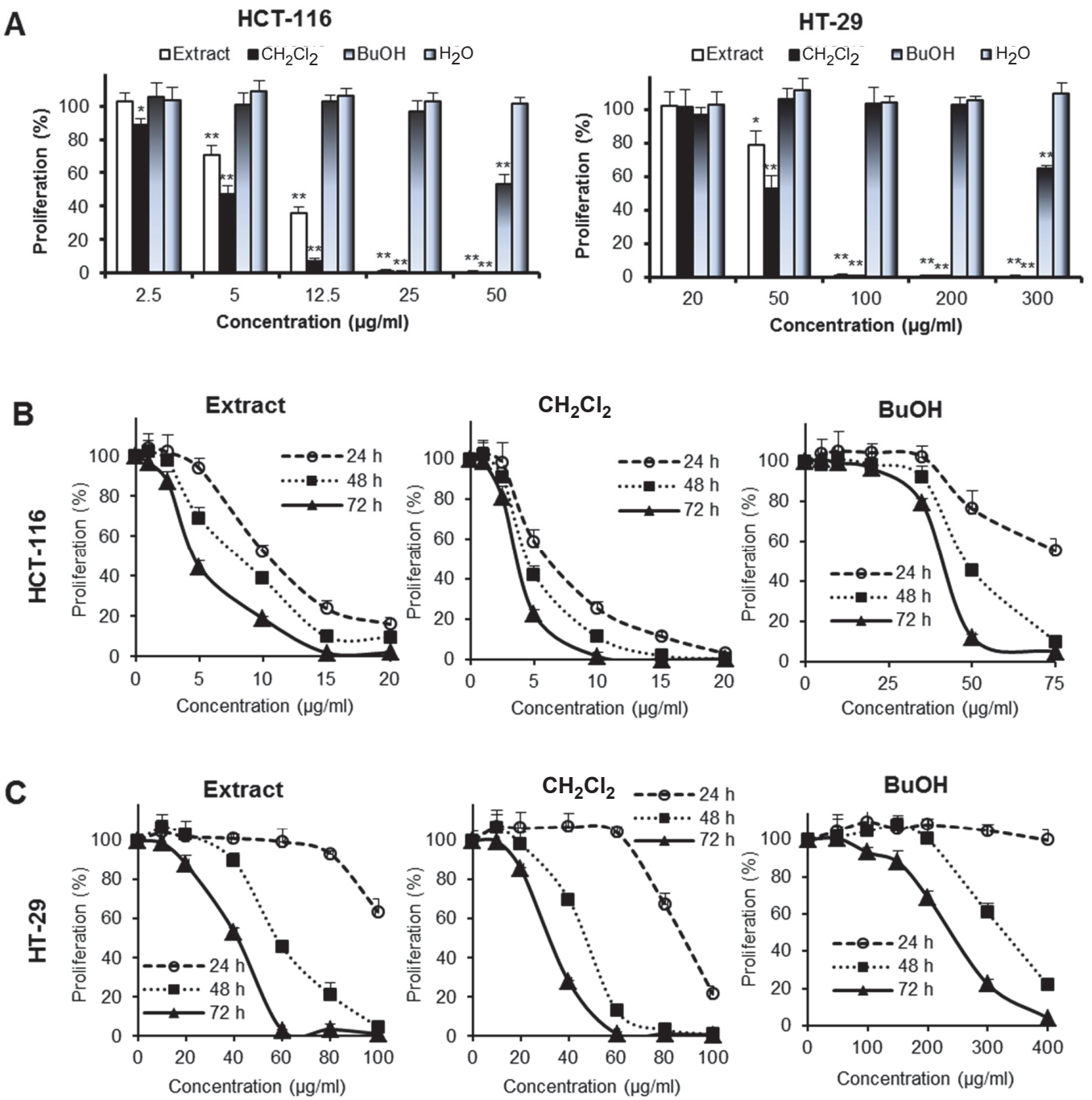

Fig. 3. Antiproliferative effects of O. elatus extract and fractions on human colorectal cancer cells. (A) HCT-116 and HT-29 cells were treated with extract/fractions at concentrations of $2.5-300 \mu \mathrm{g} / \mathrm{ml}$ for $48 \mathrm{~h}$. (B + C) Time- and dose-dependent growth inhibitory effects of extract/ fractions on colorectal cancer cell lines HCT-116 (upper panel) and HT-29 (lower panel). Cell proliferation was determined by MTS assay. Results were normalized to each control in percentage and expressed as mean \pm standard error of triplicate experiments (solvent vehicle set at $100 \%) .{ }^{*} p<0.05,{ }^{* *} p<0.01$ vs. control. $\mathrm{CH}_{2} \mathrm{Cl}_{2}$, dichloromethane fraction; $\mathrm{BuOH}, \mathrm{n}$-butanol fraction; $\mathrm{H}_{2} \mathrm{O}$, water fraction. 
showed potent antiproliferative effects with slightly weaker potential than that of $\mathrm{CH}_{2} \mathrm{Cl}_{2}$ fraction. Meanwhile, $\mathrm{BuOH}$ fraction showed dose- and time-dependent antiproliferative effects, however, the active concentrations were higher than $35 \mu \mathrm{g} / \mathrm{ml}$ (Fig. 3B). A similar trend for dose- and time-dependent effects were observed in HT-29 cells (Fig. 3C), but the active concentration ranges are higher than that of HCT-116 cells. Therefore, $\mathrm{CH}_{2} \mathrm{Cl}_{2}$ is an active fraction which is extracted from $O$. elatus extract.

\section{Apoptotic effect of 0 . elatus extract and fractions on colorectal cancer cells}

To explore the potential mechanism through which O. elatus induces cell death, we carried out an apoptotic assay by flow cytometry after staining with annexin V and PI. Based on the MTS assay data, using HCT-116 cells, an antiproliferative effect was observed by extract and $\mathrm{CH}_{2} \mathrm{Cl}_{2}$ treatment at $>2.5 \mu \mathrm{g} / \mathrm{ml}$. Thus, we used the treatment concentration range of $1-5 \mu \mathrm{g} / \mathrm{ml}$ to evaluate their effects on HCT-116 cell apoptosis. Annexin V can be detected in both the early and late stages of apoptosis. PI enters the cell in late apoptosis or necrosis. Viable cells were negative for both annexin V and PI (lower left quadrant); early apoptotic cells were positive for annexin $\mathrm{V}$ and negative for PI (lower right quadrant); late apoptotic or necrotic cells displayed both positive annexin $\mathrm{V}$ and PI (upper right quadrant); non-viable cells which underwent necrosis were positive for $\mathrm{PI}$ and negative for annexin V (upper left quadrant) - Fig. 4A (Wang et al., 2013).
A
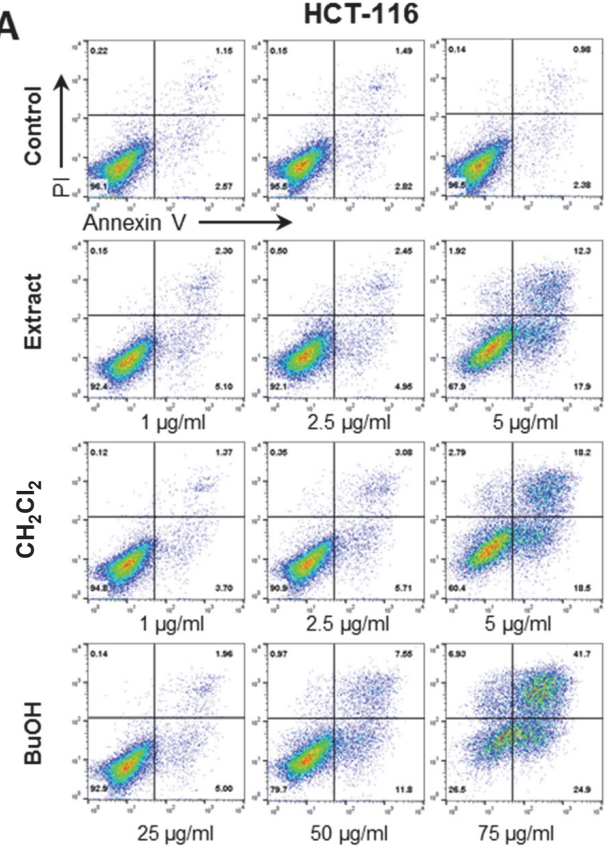

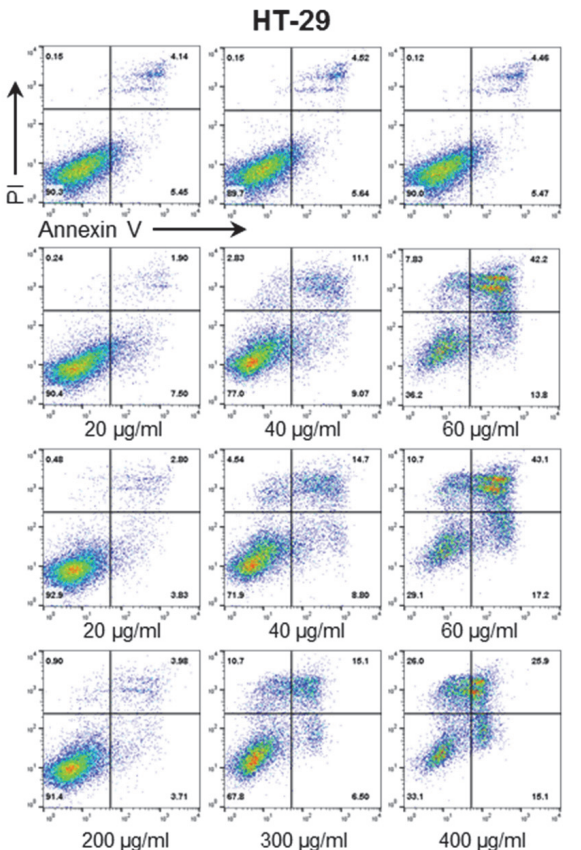

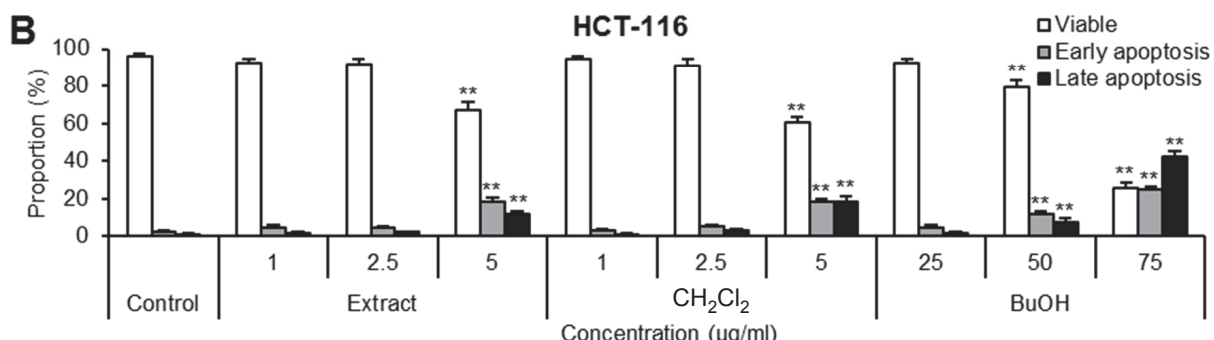

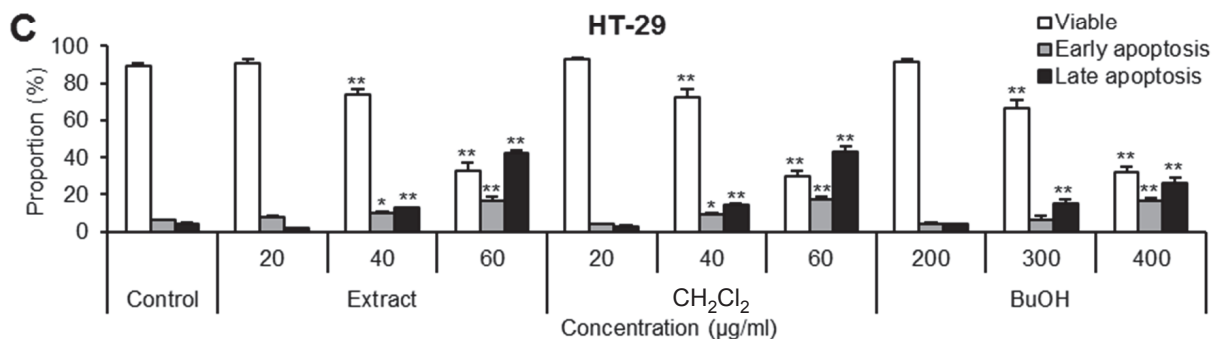

Fig. 4. Apoptotic analysis of HCT-116 and HT-29 cells treated with O. elatus extract and fractions. Cells were treated with extract/fractions for $48 \mathrm{~h}$, then stained with annexin V/propidium iodide (PI) before the extent of apoptosis was determined by flow cytometry. (A) Representative scatter plots of PI (y-axis) versus annexin V (x-axis). $(\mathbf{B}+\mathbf{C})$ Percentage of viable, early apoptotic and late apoptotic cells. Data are presented as the mean \pm standard error of triplicate experiments. ${ }^{*} p<0.05,{ }^{* *} p<0.01$ vs. control. $\mathrm{CH}_{2} \mathrm{Cl}_{2}$, dichloromethane fraction; BuOH, $\mathrm{n}$-butanol fraction. 
Due to more experiments being conducted, the horizontal and vertical axis labels for the flow cytometry density plots were removed to display the original data and reduce space size. The bar graphs summarized the effects of different groups with statistical analytical results. For the HCT-116 cell group, after treatment for $48 \mathrm{~h}$, cell percentage of the summary of early and late apoptosis for control was $3.9 \%$; for $5 \mu \mathrm{g} / \mathrm{ml}$ of extract and $\mathrm{CH}_{2} \mathrm{Cl}_{2}$ fraction was $30.6 \%$ and $36.5 \%$, respectively (Fig. 4B). BuOH also induced cell apoptosis, but active concentration was up to $50 \mu \mathrm{g} / \mathrm{ml}$. Similar results were observed in HT-29 cells, although the active concentrations are higher than that for HCT-116 cells (Fig. 4). Thus, O. elatus extract and fractions clearly induced apoptosis in both cell lines, and $\mathrm{CH}_{2} \mathrm{Cl}_{2}$ showed more potent activity than the extract. This re- sult suggested that the antiproliferative effect of $O$. elatus extract and active fraction $\left(\mathrm{CH}_{2} \mathrm{Cl}_{2}\right)$ was in part mediated by the induction of apoptosis.

\section{Effects of 0 . elatus extract and fractions on colorectal cancer cell cycle}

The cell proliferation assay results suggested that after treatment with $O$. elatus extract and fractions, cell growth was inhibited in a dose- and time-dependent manner (Fig. 3). In the apoptotic assay, we also observed that viable cells were decreased with increasing treatment concentration. To further characterize the potential mechanism of O. elatus anticancer activity, the cell cycle profile was assayed by flow cytometry after staining with propidium iodide (PI). As shown in Fig. 5A,
A
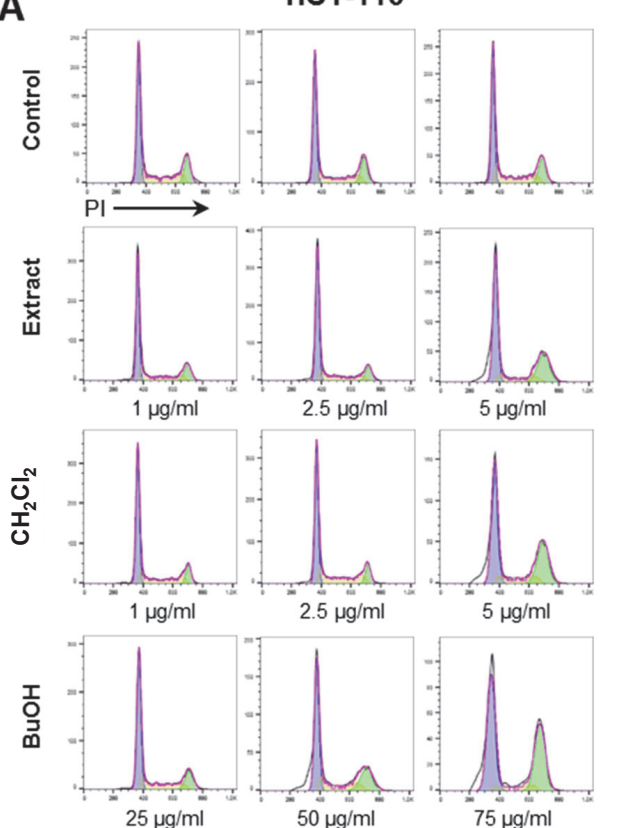

HT-29
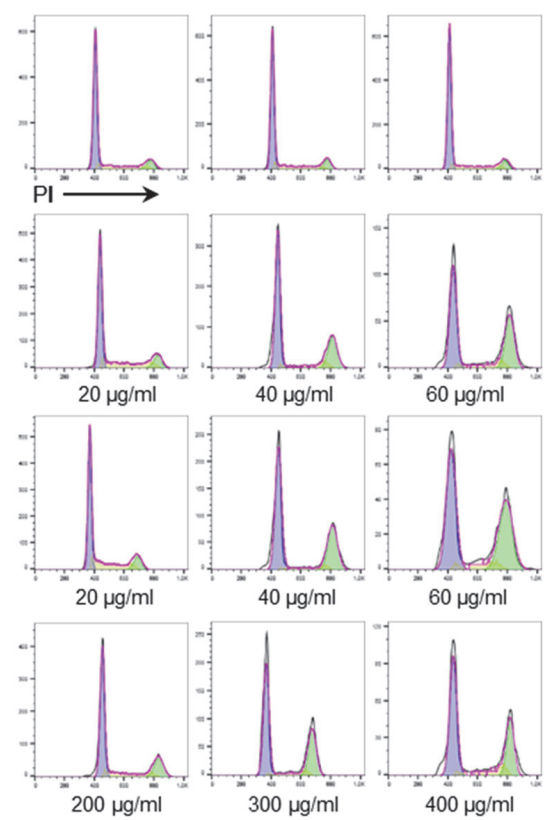

B
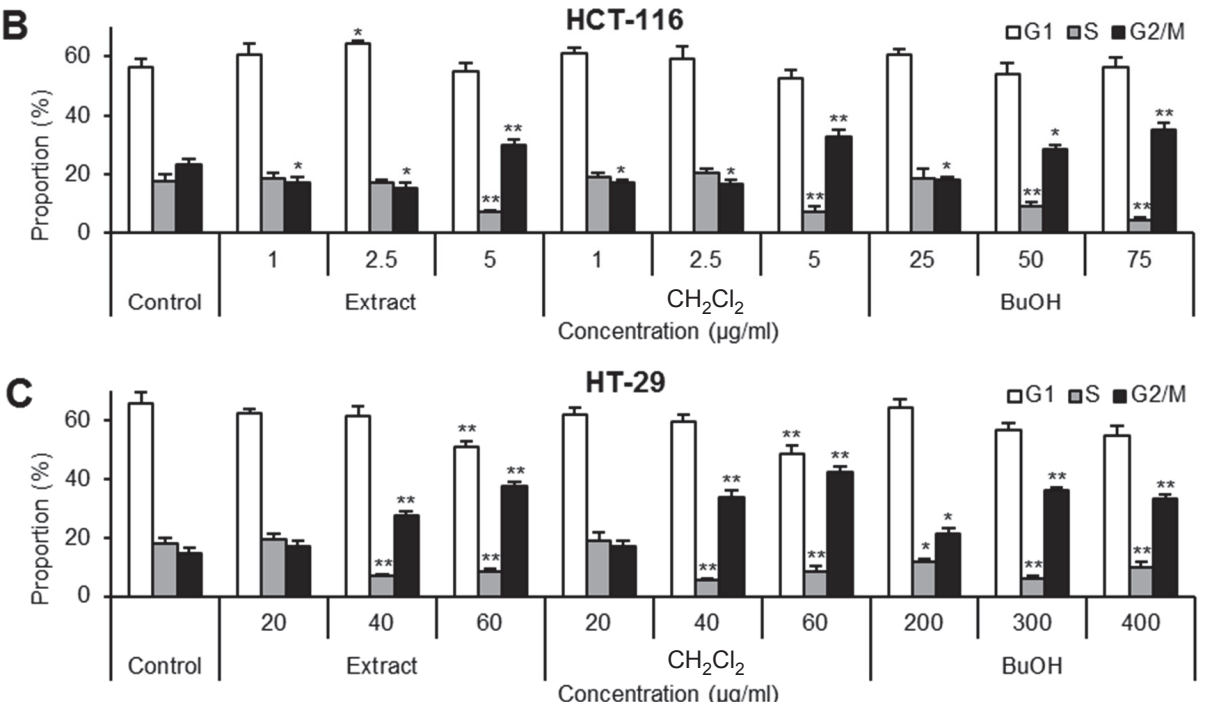

Fig. 5. Cell cycle analysis of HCT-116 and HT-29 cells treated with O. elatus extract and fractions. Cells were treated with extract/fractions for $48 \mathrm{~h}$, then fixed in ethanol and stained with propidium iodide. DNA content was determined by flow cytometry. (A) Representative histograms of the DNA content in each experimental group. $(\mathbf{B}+\mathbf{C})$ Percentage of each cell cycle phase with various treatments or with control. Data are presented as the mean \pm standard error of triplicate experiments. ${ }^{*} p<0.05$, ${ }^{* *} p<0.01$ vs. control. $\mathrm{CH}_{2} \mathrm{Cl}_{2}$, dichloromethane fraction; $\mathrm{BuOH}$, n-butanol fraction. 
compared to the control, treatment with 1 and $2.5 \mu \mathrm{g} / \mathrm{ml}$ for $48 \mathrm{~h}$ did not obviously change the cell cycle profile. However, after treatment with $5 \mu \mathrm{g} / \mathrm{ml}$, although the percentage of cells in G1-phase was slightly changed, extract and $\mathrm{CH}_{2} \mathrm{Cl}_{2}$ fraction obviously reduced the percentage of S-phase and increased G2/M-phase cells. Compared to the control $(56.6 \%$ of G1-phase, $17.9 \%$ of S-phase, and $23.4 \%$ of G2/M-phase), treatment with $5 \mu \mathrm{g} / \mathrm{ml}$ of extract, $54.9 \%$ of cells were in G1-phase, $7.1 \%$ of cells were in S-phase, and $30.1 \%$ of cells were in $\mathrm{G} 2 / \mathrm{M}$-phase; treatment with $\mathrm{CH}_{2} \mathrm{Cl}_{2}$ fraction, $52.6 \%$ of G1-phase, $7.2 \%$ of S-phase, and $32.6 \%$ of G2/M-phase (Fig. 5B). Extract and $\mathrm{CH}_{2} \mathrm{Cl}_{2}$ fraction treatment obviously decreased S-phase cells, while increasing G2/M-phase cells. In addition, treatment with $\mathrm{BuOH}$ fraction also decreased S-phase and increased G2/M-phase cells; however, the active concentration is as high as $25 \mu \mathrm{g} / \mathrm{ml}$.

A similar trend was also observed in HT-29 cells but with higher treatment concentrations. For example, compared to control $(14.7 \%$ of $\mathrm{G} 2 / \mathrm{M})$, after treatment with 40 and
$60 \mu \mathrm{g} / \mathrm{ml}$ of extract for $48 \mathrm{~h}$, cells in $\mathrm{G} 2 / \mathrm{M}$ phase were $27.6 \%$ and 37.5 , respectively; while for $\mathrm{CH}_{2} \mathrm{Cl}_{2}$ fraction treatment, $33.7 \%$ and $42.4 \%$ of cells were arrested in $\mathrm{G} 2 / \mathrm{M}$ phase, respectively. Although $\mathrm{BuOH}$ showed $\mathrm{G} 2 / \mathrm{M}$ phase arrest effects in much higher concentrations $(300-400 \mu \mathrm{g} / \mathrm{ml})$, among extract and fractions, $\mathrm{CH}_{2} \mathrm{Cl}_{2}$ showed the strongest cell cycle arrest potential.

\section{Effects of 0 . elatus extract and fractions on expression of cyclin A}

Since cell cycle progression is regulated by the cyclins, and cyclin $A$ is a key regulator for the passage through $G 2 / M-$ phase (Zhao et al., 2016), to observe the regulation proteins involved in the cell cycle arrest, the expression of cyclin A in HCT-116 and HT-29 cancer cells was evaluated (Fig. 6A). For the HCT-116 cells, at $48 \mathrm{~h}$, the percentage of cyclin A positive cells in the untreated control was $8.6 \%$. With treatment concentrations of 2.5 and $5 \mu \mathrm{g} / \mathrm{ml}$, for the extract, the proportion of cyclin A positive cells increased to $14.6 \%$ and $16.5 \%$,
A
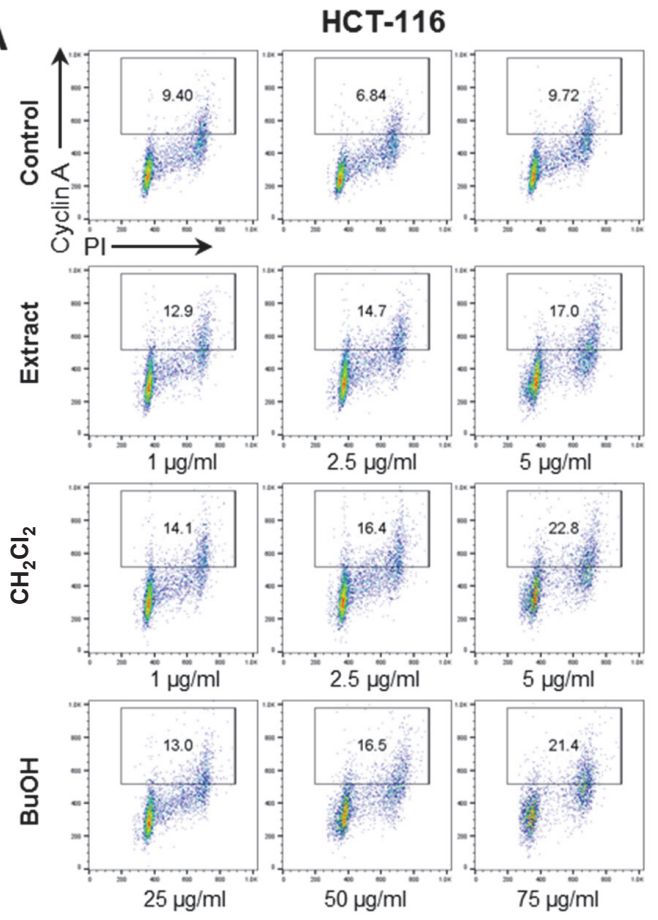
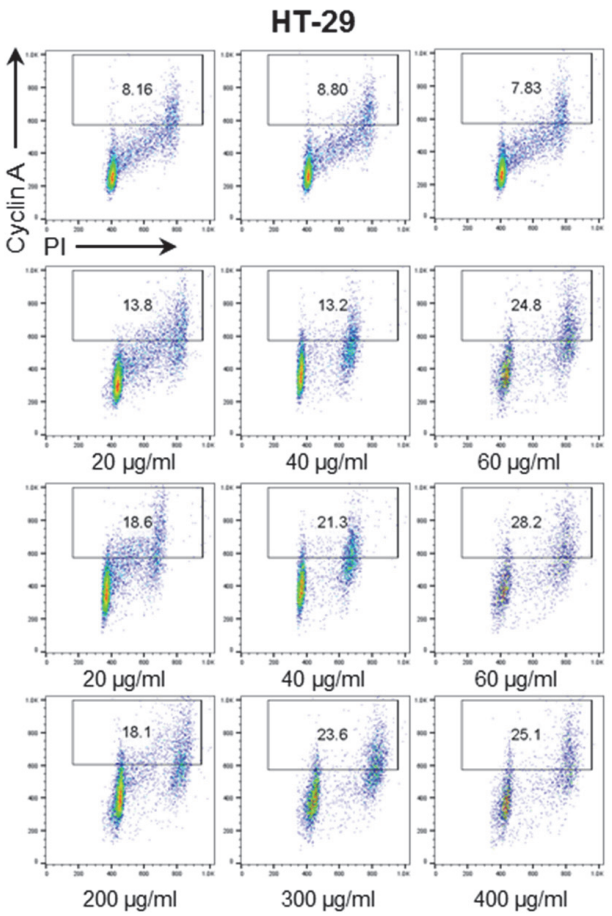
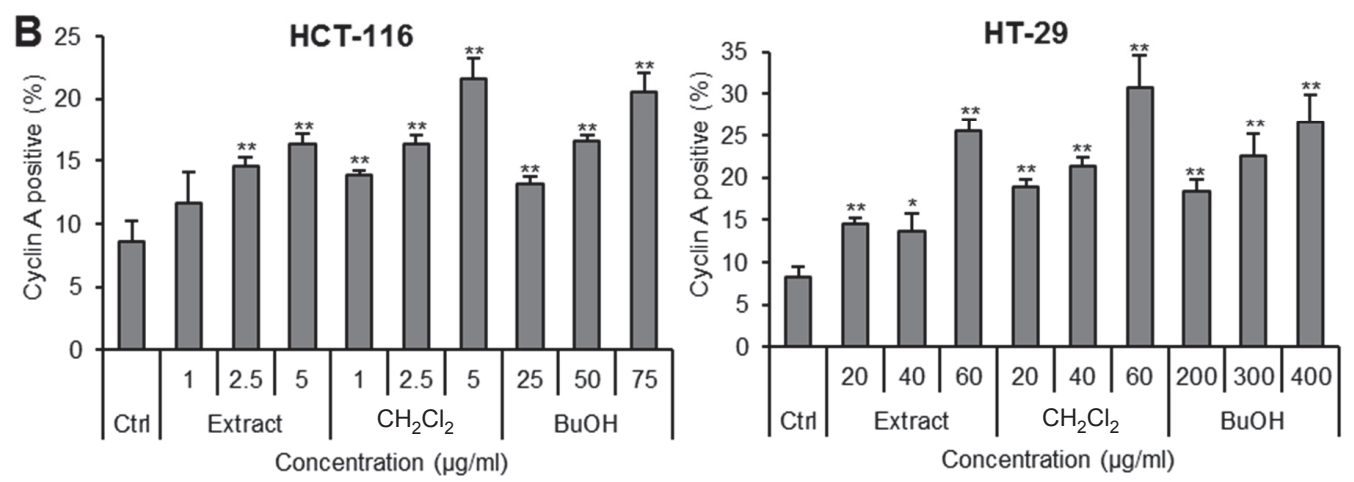

Fig. 6. Expression of cyclin A analysis of HCT-116 and HT-29 cells treated with O. elatus extract and fractions. Cells were treated with extract/ fractions for $48 \mathrm{~h}$, then fixed in ethanol and stained with propidium iodide and cyclin A. (A) Representative scatter plots of cyclin A (y-axis) versus PI (x-axis), and the percentage of cyclin A positive cells is shown in the gate. (B) Percentage of cyclin A positive cells with various treatments or with control. Data are presented as the mean \pm standard error of triplicate experiments. ${ }^{*} p<0.05,{ }^{* *} p<0.01$ vs. control. $\mathrm{CH}_{2} \mathrm{Cl}_{2}$, dichloromethane fraction; $\mathrm{BuOH}$, n-butanol fraction. 
respectively; for the $\mathrm{CH}_{2} \mathrm{Cl}_{2}$ fraction, they were increased to $16.4 \%$ and $21.6 \%$, respectively (Fig. $6 \mathrm{~B}$ ). Similar results were also observed in HT-29 cells. Compared to control (8.3\%), $48 \mathrm{~h}$ treatment with 40 and $60 \mu \mathrm{g} / \mathrm{ml}$ of extract and $\mathrm{CH}_{2} \mathrm{Cl}_{2}$ fraction increased cyclin A positive cell proportions to $25.5 \%$ and $30.7 \%$, respectively. BuOH fraction also arrested cell cycle in G2/M phase in both cell lines, but active concentrations are relatively high. Therefore, treatment with $O$. elatus extract and fractions caused a marked increase in the expression of cyclin A on human colorectal cancer cells, of which $\mathrm{CH}_{2} \mathrm{Cl}_{2}$ showed more potent activity.

\section{Identification of active compound from 0 . elatus}

To evaluate the contribution of representative single compounds to the antiproliferative activities of the extract and different fractions, two isolated polyynes were used to test their effects on HCT-116 and HT-29 cells. HPLC analysis showed that the major constituents in the O. elatus extract are fal- carindiol and oplopandiol. They are also the major components in $\mathrm{CH}_{2} \mathrm{Cl}_{2}$ and $\mathrm{BuOH}$ fractions. As shown in Fig. 7A, for the HCT-116 cell line, treatment with $1-5 \mu \mathrm{M}$ of oplopandiol for $48 \mathrm{~h}$ yielded no observable cell inhibitory effect, while at 2 and $5 \mu \mathrm{M}$, falcarindiol inhibited cell growth by $68.8 \%$ and $97.4 \%$ (both $p<0.01$ vs. control), respectively. The IC50 for falcarindiol and oplopandiol was $1.7 \mu \mathrm{M}$ and $15.5 \mu \mathrm{M}$, respectively. For the HT-29 cell line, oplopandiol did not show obvious antiproliferative effects up to $40 \mu \mathrm{M}$. Falcarindiol showed significant antiproliferative effects at 10 and $20 \mu \mathrm{M}(p<0.01 \%)$, and IC50 of falcarindiol was $13.2 \mu \mathrm{M}$, in comparison to oplopandiol of $>60 \mu \mathrm{M}$ (Fig. 7B). These two compounds were found to have the highest contents in the extract and the active $\mathrm{CH}_{2} \mathrm{Cl}_{2}$ fraction, which represents the biological effects of the extract and fraction. Because oplopandiol showed low to moderate activity, while falcarindiol showed very potent antiproliferative effects, falcarindiol has been identified as an active constituent in the O. elatus.
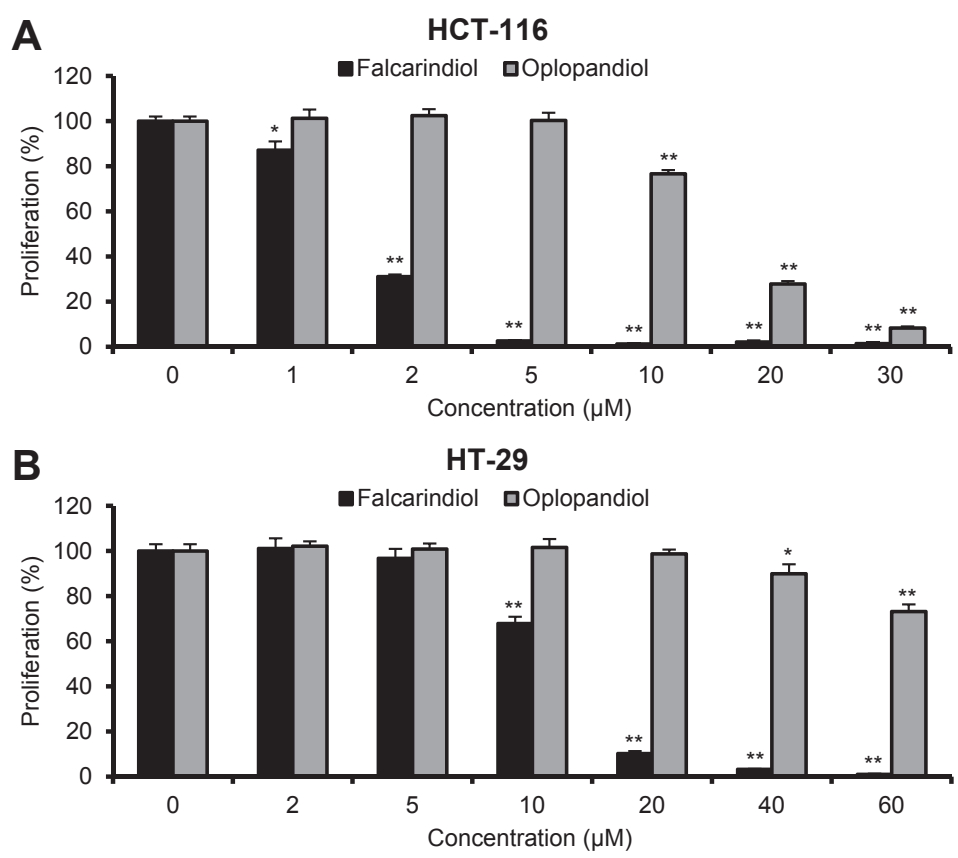

Fig. 7. Antiproliferative effects of falcarindiol and oplopandiol on human colorectal cancer cell lines HCT-116 (A) and HT-29 (B) Cancer cells were exposed to compounds $(1-60 \mu \mathrm{M})$ for $48 \mathrm{~h}$ and cell proliferation was determined by the MTS assay. The results are expressed as the mean \pm standard error of triplicate experiments. ${ }^{*} p<0.05$; ${ }^{* *} p<0.01$ vs. control.

\section{Discussion}

Human colorectal cancer is a leading cause of cancer-related death in the United States and worldwide. Half of all patients diagnosed with colorectal cancer eventually die from the disease; only less than $10 \%$ of patients with metastatic colorectal cancer will survive more than five years after diagnosis (Siegel et al., 2021). A number of recent controlled clinical trials supported a multimodal and multidisciplinary approach (including a combination of treatments and the schedule in which they are administered) to treating both early and advanced stages of colorectal cancer (Hurwitz et al., 2004; Redondo-Blanco et al., 2017). Studies also showed that patients with cancer often resort to complementary and alternative medical means to treat cancer, cancer-related symptoms, and/or to reduce the side effects of chemotherapy (Cragg et al., 2009; Wang et al., 2012a). An estimated $30-50 \%$ of cancer patients use complementary and alternative medicines, including herbal medicines, along with their conventional medication (Buckner et al., 2018; Ernst 2000). While some beneficial effects of selected botanicals are documented, there are limited data to indicate whether herbs are effective in cancer therapeutics, and their mechanisms of action are unexplained as of now (Masui et al., 2013).

Plants from Oplopanax genus have been used as herbal medicines, and O. horridus has mainly been used by the Pacific indigenous peoples. In fact, O. horridus has reportedly been used by people from over 38 linguistic groups for the treatment of upwards of 34 different medical conditions (Lantz et al., 2004). In comparison to the long history ethnic medical use of Oplopanax plants, modern pharmacological studies on 
this group of herbs are relatively fewer. O. horridus is a north American native botanical. Regarding Oplopanax species, most phytochemical and pharmacological reports are focused on this species (Calway et al., 2012; Huang et al., 2014). Several reports, including ours, indicated that $O$. horridus extract and dichloromethane fraction possess significant anticancer potential, and active constituents in this herb are identified as a group of polyynes (Sun et al., 2010; Wang et al., 2013). However, because many polyynes were identified from $O$. horridus and the contents of polyynes in the herbal extract are very low, it is difficult to standardize the herbal extract or fractions with polyynes (Huang et al., 2010).

O. elatus is another species in the genus Oplopanax. Recent studies have shown that $O$. elatus has significant anticancer activity (Wang et al., 2019a, b). Moreover, because there are only two major polyynes in the extract, the constituents in the herb are not as complicated as $O$. horridus, which makes it much easier than $O$. horridus to standardize the extract or active fraction. In this study, phytochemical and biological investigations were conducted on this herbal medicine.

We prepared three fractions by using dichloromethane and n-butanol extraction. Our pilot data showed that only two major constituents were found in the O. elatus extract and fractions. Thus, single compound isolation was focused on these compounds. With efficient preparative HPLC, we isolated these two compounds and identified them as falcarindiol and oplopandiol. HPLC analysis showed that these two compounds have relatively high content in the extract $(72.7 \%)$. After dichloromethane extraction, the content of these two compounds was increased to $81.2 \%$. Thus, polyyne content in the O. elatus extract and dichloromethane fraction is much higher than that in O. horridus extract and fraction (Huang et al., 2010; Sun et al., 2010). Analytical data encouraged us that O. elatus components may have stronger anticancer effects than O. horridus.

Using MTS assay, the antiproliferative effects of O. elatus and three fractions were determined. The whole extract inhibited colon cancer cell growth. The dichloromethane fraction $\left(\mathrm{CH}_{2} \mathrm{Cl}_{2}\right)$ showed more potent antiproliferative effects than the extract. In contrast, the water fraction $\left(\mathrm{H}_{2} \mathrm{O}\right)$ did not show any antiproliferative effect. In addition, the n-butanol fraction $(\mathrm{BuOH})$ showed weak antiproliferative effects due to low content of polyynes. We recognized that the $\mathrm{CH}_{2} \mathrm{Cl}_{2}$ fraction is an active antiproliferative fraction.

Apoptosis is programmed cell death, a highly regulated process used to eliminate unwanted or defective cells (Wang et al., 2012b). Many chemotherapeutic agents, natural compounds, radiation, immunotherapy, and cytokines induce cancer cell death via the apoptotic pathway (Friedman, 2002). We observed O. elatus extract and fractions on the apoptotic induction of HCT-116 and HT-29 cells. The total extract and two fractions obviously induced cell apoptosis, while the active concentration for $\mathrm{BuOH}$ is relatively high. The $\mathrm{CH}_{2} \mathrm{Cl}_{2}$ fraction, which possessed the most potent anti-proliferative activity, has been identified as an active fraction. The $\mathrm{CH}_{2} \mathrm{Cl}_{2}$ fraction showed the strongest apoptotic induction activity (Fig. 4). This result suggests that antiproliferation of $O$. elatus extract and active fraction on human colorectal cancer cells is mediated in part by the induction of apoptosis.

Cancer cells lack normal growth controls, exhibit loss of cell cycle control, have unlimited reproductive potential, and have growth-signal self-sufficiency. Any compound aimed at controlling these processes would be beneficial in suppressing cancer progression (Lin et al., 2017). We investigated the effects of $O$. elatus extract and fractions on the cancer cell cycle.
In low concentrations, the extract and $\mathrm{CH}_{2} \mathrm{Cl}_{2}$ fraction decreases the $\mathrm{S}$-phase and mainly arrests cells in the G2/M-phase but does not influence the proportion of the G1-phase (Fig. 5). $\mathrm{G} 2 / \mathrm{M}$ phase arrest was also observed in $\mathrm{BuOH}$ fraction, but only in high treatment concentration. Both cell lines showed a similar trend, while active concentration on HT-29 cells is higher than on HCT-116 cells.

Since cyclins and cyclin-dependent kinases regulate cell cycle progression, and cyclin $\mathrm{A}$ is an important regulator of G2/M events (Zhao et al., 2016), we determined the expression of cyclin A in relation to the extract and fractions' G2/Mphase arrest. After treatment with $\mathrm{CH}_{2} \mathrm{Cl}_{2}$ fraction for $48 \mathrm{~h}$ (5 $\mu \mathrm{g} / \mathrm{ml}$ for HCT-116, $60 \mu \mathrm{g} / \mathrm{ml}$ for HT-29), the fraction of cyclin A positive cells increased to $21.7 \%$ for HCT-116 and $30.7 \%$ for HT-29 cells; in untreated cells, the fraction was only $8.7 \%$ and $8.3 \%$, respectively (Fig. 6). Because the accumulation of cyclin A was critical to promote cell cycle arrest in the G2/Mphases, our data proved that the active $\mathrm{CH}_{2} \mathrm{Cl}_{2}$ fraction-induced G2/M-phase arrest was regulated by the key cell cycle regulator cyclin $\mathrm{A}$.

The biological activity of Oplopanax plants is the result of polyynes, which is believed to be the main active constituents in the herbs (Huang et al., 2014). While several but low content polyynes were detected in O. horridus extract (Huang et al., 2010), in this study, we demonstrated that in O. elatus, only two major polyynes were determined. These two polyynes were used to test for antiproliferative effects on colorectal cancer cells. From the results shown in Fig. 7, oplopandiol did not show a potent antiproliferative effect up to $10 \mu \mathrm{M}$ on HCT-116 cells and $40 \mu \mathrm{M}$ on HT-19 cells. In contrast, at much lower concentrations ( $2 \mu \mathrm{M}$ on HCT-116, and $10 \mu \mathrm{M}$ on HT-29), falcarindiol showed very potent antiproliferative effects. Falcarindiol's IC50 for HCT-116 cells was $1.7 \mu \mathrm{M}$ (vs. oplopandiol of $15.5 \mu \mathrm{M}$ ) and, for HT-29 cells, was $13.2 \mu \mathrm{M}$, in comparison to oplopandiol of $>60 \mu \mathrm{M}$. Thus, falcarindiol has been identified as an active constituent in the extract and active fraction. The chemopreventive mechanisms of falcarindiol in cancer cells and related illness will be investigated in our future studies. Because falcarindiol occupied a proportion of approximately $16 \%$ in the extract and active fraction, the cancer cell growth inhibition of $O$. elatus is a major contributor by falcarindiol. Due to the relatively simple composition in the herb and active fraction, in future studies, falcarindiol is a reasonable selection in standardizing herbal extract or active fraction.

To investigate responses of herbal components in different types of cancer cells, we employed two human colorectal cancer cell lines varied in p53 expression. HCT-116 is p53 wild type, while HT-29 cells contain a p53 mutation (Watson et al., 2010). Cancer cells with p53 mutations are resistant to many chemotherapeutic agents (Fan et al., 2014). Exposure to cellular stress triggered the p53 tumor suppressor and induced cell cycle arrest and apoptosis (Yogosawa and Yoshida, 2018). Our data showed that HCT-116 cells were more sensitive than HT-29 cells. Compared to HT-29, lower concentration of extract/fraction treatment inhibited HCT-116 cell growth, indicating that p53 plays a role in O. elatus-mediated colon cancer cell growth inhibition.

\section{Conclusions}

In summary, due to the limited reports available, the chemical composition and biological functions of $O$. elatus are still unknown. Our study filled the gap between the phytochemical basis and its potential in colorectal cancer chemoprevention. 
HPLC analysis supplied original information of constituents in O. elatus extract and fractions, including the essential structural information of detected constituents. Pharmacological data obtained from this study suggested that O. elatus possesses significant chemopreventive potential on different types of human colorectal cancer cells. The dichloromethane fraction is an active fraction, and an active constituent has been identified as falcarindiol. The mechanisms involved in cancer chemoprevention by $O$. elatus were induction of apoptosis and cell cycle arrest at the G2/M phase mediated by a key cell cycle regulator cyclin A.

\section{Acknowledgements}

This work was supported in part by NIH/NCCAM grants P01 AT004418 and K01 AT005362, the grants of the National Natural Science Foundation of China (81760711), and the State Scholarship Fund of China Scholarship Council (201808360056).

\section{Author contributions}

CZW, WD, MX and CSY designed the study, set up the experiments, participated in data collection, analyzed and interpreted the results, and drafted the manuscript. YL, WHH, JZ, CFZ and LC carried out some experiments and participated in the related data interpretations. All authors have read and approved the final manuscript.

\section{Conflict of interests}

The authors declare that they have no conflict of interests.

\section{References}

Buckner CA, Lafrenie RM, Denommee JA, Caswell JM, Want DA (2018). Complementary and alternative medicine use in patients before and after a cancer diagnosis. Curr Oncol 25: e275-e281. DOI: $10.3747 /$ co.25.3884.

Calway T, Du G-J, Wang C-Z, Huang W-H, Zhao J, Li S-P, Yuan C-S (2012). Chemical and pharmacological studies of Oplopanax horridus, a North American botanical. J Nat Med 66: 249-256. DOI: 10.1007/s11418-011-0602-2.

Changchun College of Traditional Chinese Medicine (1970). Jilin Chinese Herbal Medicine Jilin People's Press.

Cragg GM, Grothaus PG, Newman DJ (2009). Impact of natural products on developing new anti-cancer agents. Chem Rev 109: 3012-3043. DOI: 10.1021/cr900019j.

Editorial Committee for Chinese Materia Medica (1999). Oplopanax elatus Nakai. Chinese Materia Medica. Shanghai: Shanghai Scientific and Technical Publishers.

Ernst E (2000). The role of complementary and alternative medicine in cancer. Lancet Oncol 1: 176-180. DOI: 10.1016/s14702045(00)00031-0.

Fan YN, Meley D, Pizer B, Sée V (2014). Mir-34a mimics are potential therapeutic agents for p53-mutated and chemo-resistant brain tumour cells. PloS One 9: e108514. DOI: 10.1371/journal. pone. 0108514 .

Friedman EJ (2002). Immune modulation by ionizing radiation and its implications for cancer immunotherapy. Curr Pharm Des 8: 1765-1780. DOI: 10.2174/1381612023394089.

Fu A, Zhang H, Zhang L (1997). Clinical and laboratory studies of the essential oil from Oplopanax elatus Nakai against fungi. Chin J Dermatol 30: 310-311.

Huang W-H, Yang J, Zhao J, Wang C-Z, Yuan C-S, Li S-P (2010). Quantitative analysis of six polyynes and one polyene in Oplopanax horridus and Oplopanax elatus by pressurized liquid extraction and on-line SPE-HPLC. J Pharm Biomed Anal 53: 906-910. DOI: 10.1016/j.jpba.2010.06.021.
Huang W-H, Zhang Q-W, Yuan C-S, Wang C-Z, Li S-P, Zhou H-H (2014). Chemical constituents of the plants from the genus Oplopanax. Chem Biodivers 11: 181-196. DOI: 10.1002/ cbdv.201200306.

Huang Y, Zhu J, Lin X, Hong Y, Feng Y, Shen L (2019). Potential of fatty oils from traditional Chinese medicine in cancer therapy: A review for phytochemical, pharmacological and clinical studies. Am J Chin Med 47: 727-750. DOI: 10.1142/ S0192415X19500381.

Hurwitz H, Fehrenbacher L, Novotny W, Cartwright T, Hainsworth J, Heim W, et al. (2004). Bevacizumab plus irinotecan, fluorouracil, and leucovorin for metastatic colorectal cancer. N Engl J Med 350: 2335-2342. DOI: 10.1056/NEJMoa032691.

Jang M, Lee Y-C, Hong H-D, Rhee YK, Lim T-G, Kim K-T, et al. (2017). Anti-oxidative and anti-inflammatory activities of devil's club (Oplopanax horridus) leaves. Food Sci Biotechnol 26: 213-220. DOI: 10.1007/s10068-017-0029-y.

Klimakova AI, Kazman MA (1962). Echinopanax tincture in complex therapy of patients with diabetes mellitus. In: Turova AD (Ed.). Medicinal Preparations from Plants. Moscow: Soviet Muscovite Press, pp. 250-258.

Kwon KS, Lim H, Kwon YS, Kim MJ, Yoo JH, Yoo NH, Kim HP (2020). Inhibitory mechanisms of water extract of Oplopanax elatus on lipopolysaccharide-induced inflammatory responses in RAW 264.7 murine macrophage cells. Chin J Integr Med 26: 670-676. DOI: 10.1007/s11655-020-3188-2.

Lantz TC, Swerhun K, Turner NJ (2004). Devil's club (Oplopanax horridus): An ethnobotanical review. Herbal Gram 62: 33-48.

Lee D-Y, Park CW, Lee SJ, Park H-R, Seo DB, Park JY, et al. (2019). Immunostimulating and antimetastatic effects of polysaccharides purified from ginseng berry. Am J Chin Med 47: 823-839. DOI: 10.1142/S0192415X19500435.

Lin AB, McNeely SC, Beckmann RP (2017). Achieving precision death with cell-cycle inhibitors that target DNA replication and repair. Cliln Cancer Res 23: 3232-3240. DOI: 10.1158/1078-0432.CCR16-0083.

Liu B, Ding L, Zhang L, Wang S, Wang Y, Wang B, Li L (2019). Baicalein induces autophagy and apoptosis through AMPK pathway in human glioma cells. Am J Chin Med 47: 1405-1418. DOI: 10.1142/S0192415X19500721.

Masui K, Gini B, Wykosky J, Zanca C, Mischel PS, Furnari FB, Cavenee WK (2013). A tale of two approaches: complementary mechanisms of cytotoxic and targeted therapy resistance may inform next-generation cancer treatments. Carcinogenesis 34: 725-738. DOI: 10.1093/carcin/bgt086.

Qiao X, Sun W, Wang C, Zhang L, Li P, Wen X, et al. (2017). Polyyneenriched extract from Oplopanax elatus significantly ameliorates the progression of colon carcinogenesis in Apc Min/+ mice. Molecules 22: 1593. DOI: 10.3390/molecules22101593.

Redondo-Blanco S, Fernández J, Gutiérrez-Del-Río I, Villar CJ, Lombó F (2017). New insights toward colorectal cancer chemotherapy using natural bioactive compounds. Front Pharmacol 8: 109. DOI: 10.3389/fphar.2017.00109.

Shikov AN, Pozharitskaya ON, Makarov VG, Yang W-Z, Guo D-A (2014). Oplopanax elatus (Nakai) Nakai: chemistry, traditional use and pharmacology. Chin J Nat Med 12: 721-729. DOI: 10.1016/ S1875-5364(14)60111-4.

Siegel RL, Miller KD, Fuchs HE, Jemal A (2021). Cancer Statistics, 2021. CA Cancer J Clin 71: 7-33. DOI: 10.3322/caac. 21654.

Sun S, Du G-J, Qi L-W, Williams S, Wang C-Z, Yuan C-S (2010). Hydrophobic constituents and their potential anticancer activities from Devil's Club (Oplopanax horridus Miq.). J Ethnopharmacol 132: 280-285. DOI: 10.1016/j.jep.2010.08.026.

Tai J, Cheung S, Cheah S, Chan E, Hasman D (2006). In vitro antiproliferative and antioxidant studies on Devil's Club Oplopanax horridus. J Ethnopharmacol 108: 228-235. DOI: 10.1016/j. jep.2006.05.018.

Tian GR, Zhang SC, Wang XR (1985). The treatment of chronic rheumatic arthritis by Oplopanax elatus: 123 cases. Jilin J Tradit Chin Med 7: 11.

Tian W, Piao X-M, Yin C-R, Jiang X-L, Sun H-D, An X-L, et al. (2019). Adventitious root cultures of Oplopanax elatus inhibit LPS-induced inflammation via suppressing MAPK and NF-kappaB signaling 
pathways. In Vitro Cell Dev Biol Anim 55: 766-775. DOI: 10.1007/ s11626-019-00396-7.

Turova AD (1974). Medicinal Plants of USSR and their Applications. Medizina.

Vereshchagin IA, Geskina OD, Bukhteeva ER (1982). Increasing of antibiotic therapy efficacy with adaptogens in children suffering from dysentery and Proteus infection. Antibiotiki 27: 65-69.

Wang C-Z, Calway T, Yuan C-S (2012a). Herbal medicines as adjuvants for cancer therapeutics. Am J Chin Med 40: 657-669. DOI: $10.1142 / S 0192415 X 12500498$.

Wang C-Z, Du G-J, Zhang Z, Wen X-D, Calway T, Zhen Z, et al. (2012b). Ginsenoside compound K, not Rb1, possesses potential chemopreventive activities in human colorectal cancer. Int J Oncol 40: 1970-1976. DOI: 10.3892/ijo.2012.1399.

Wang C-Z, Zhang Z, Huang W-H, Du G-J, Wen X-D, Calway T, et al. (2013). Identification of potential anticancer compounds from Oplopanax horridus. Phytomedicine 20: 999-1006. DOI: 10.1016/j. phymed.2013.04.013.

Wang J, Shao L, Rao T, Zhang W, Huang W-H (2019a). Chemopreventive potential of falcarindiol-enriched fraction from Oplopanax elatus on colorectal cancer interfered by human gut microbiota. Am J Chin Med 47: 1381-1404. DOI: 10.1142/ S0192415X1950071X.
Wang J, Shao L, Wang C-Z, Zhou H-H, Yuan C-S, Huang W-H (2019b). Synergetic inhibition of human colorectal cancer cells by combining polyyne-enriched fraction from Oplopanax elatus and irinotecan. Nutr Cancer 71: 472-482. DOI: 10.1080/01635581.2018.1516788.

Watson JL, Hill R, Yaffe PB, Greenshields A, Walsh M, Lee PW, et al (2010). Curcumin causes superoxide anion production and p53independent apoptosis in human colon cancer cells. Cancer Lett 297: 1-8. DOI: 10.1016/j.canlet.2010.04.018.

Wu H-T, Liu Y-E, Hsu K-W, Wang Y-F, Chan Y-C, Chen Y, Chen D-R (2020). MLL3 induced by luteolin causes apoptosis in tamoxifenresistant breast cancer cells through H3K4 monomethylation and suppression of the PI3K/AKT/mTOR pathway. Am J Chin Med 48: 1221-1241. DOI: 10.1142/S0192415X20500603.

Yogosawa S, Yoshida K (2018). Tumor suppressive role for kinases phosphorylating p53 in DNA damage-induced apoptosis. Cancer Sci 109: 3376-3382. DOI: 10.1111/cas.13792.

Zhao L, Miao H-C, Li W-J, Sun Y, Huang S-L, Li Z-Y, Guo Q-L (2016). LW-213 induces G2/M cell cycle arrest through AKT/GSK3beta/ beta-catenin signaling pathway in human breast cancer cells. Mol Carcinog 55: 778-792. DOI: 10.1002/mc.22321. 